Jap. J. M. Sc. \& Biol., 11, 235-249, 1958

\title{
SOME ASPECTS OF BACTERIAL MUTATION FROM STREPTO- MYCIN DEPENDENCE TO NONDEPENDENCE IN A STRAIN OF TUBERCLE BACILLI
}

\author{
KOOMI KANAI, SHigeRU KATSUYAMA,, MaKoto NAKAJIMA, \\ TOHRU MAEDA AND YONEO MARUYAMA \\ Department of Tuberculosis, National Institute of Health, Tokyo
}

(Received: August 18th, 1958)

Since the first description of streptomycin dependent strains Meningococcus by Miller and Bonhoff (1947), there have been presented many reports of such strains of microorganisms; for instance, of Brucella melitensis by Herzberg and Elberg (1953), of Salmonella enteritidis by Ushiba and others (1951), and of Mycobacterium by Yegian and others (1948, 1949), Lenert and Hobby (1949), Murata (1953), Hashimoto (1955) and Koseki (1957). It is generally accepted that streptomycin dependent cells occur as a result of bacterial mutation. Most of the above authors added their observations that "back mutation" was also possible to occur in their respective dependent strains. Paine and Finland (1948) stated that dependence upon streptomycin is a reversible phenomenon. Brief survey of those literatures indicates, however, that "back mutants" they obtained were not always streptomycin sensitive, but in some cases they were resistant to the drug.

The biological significance of streptomycin dependence of bacteria is not yet quite clear, but the "back mutation", namely variation from streptomycin dependence to nondependence, is a suitable test material for the study of bacterial mutation, especially of induced mutation, as suggested by Demerec and others (1949) and Bertani (1951).

With the same object in mind, the present authors have also been conducting some experiments using a streptomycin dependent strain of tubercle bacilli. This strain was originally isolated by Hashimoto (1955) from a streptomycin sensitive strain of human tubercle bacilli (H2) in a single step according to the method of Yegian and others (1949). This strain has been extremely stable in its dependency upon streptomycin during the period so far maintained. In addition, it was proved that nondependent variants occur in this strain at a constant rare mutation rate. If the dependent strain occurred by the single gene mutation in a streptomycin sensitive cell, then "back mutation", in the strict sense of the word, must be applied only to the case of mutational change from dependence to sensitive and not to the case of the change to resistance. However, in the course of the present research study, the authors came across an interesting observation which appears

金井興美・勝山茂・中島誠・前田幑・丸山米夫（国立予防衛生研究所結核部） 
to indicate that in some cases nondependent mutants are not due to the true back mutation, but due to a different mutation enabling them survive in nonstreptomycin environment. The similar situations can be cited from the reports of Escherichia coli by Wollman (1946) and of Neurospora by Yanofsky (1956), each concerning metabolic deficiency. In this paper, the authors will present the feature of occurrence of nondependent mutants and some of their biological characteristics.

\section{Methods and Matertals}

Culture medium: Ogawa egg medium slants were used throughout the present study. They were prepared as follows.

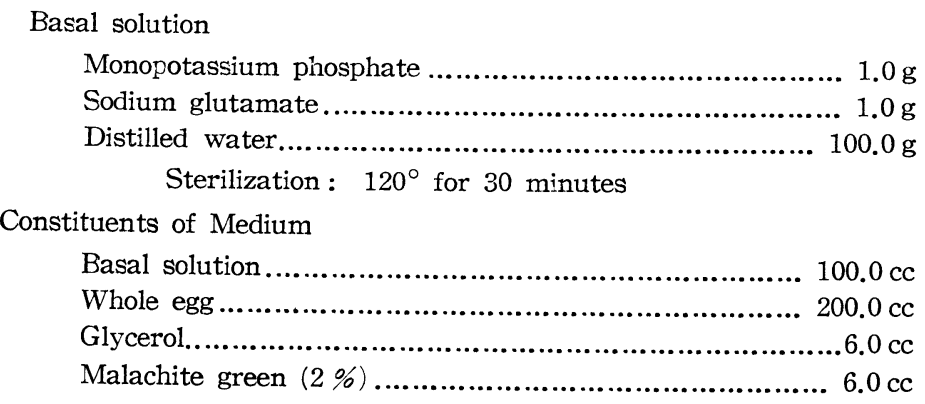

Sterilization and Coagulation: $90^{\circ} \mathrm{C}$ for 60 minutes, being dispensed to test tubes in the amount of $6 \mathrm{cc}$ in a slant position.

Streptomycin was added in due amounts taking the previous experience into our consideration that the potence of added streptomycin is reduced to one third of the original while coagulation and sterilization at $90^{\circ} \mathrm{C}$ for 60 minutes. Dihydrostreptomycin was used. With respect to isoniazid, no such consideration is necessary.

Strains of tubercle bacilli: One of the representative stock cultures of tubercle bacilli in the authors' laboratory is H2 strain. A streptomycin dependent variant strain was previously isolated on a Kirchner agar plate sown with a heavy inoculum of H2 strain by Hashimoto (1955), and named 18b strain. The present study started with a lyophilized material of this dependent strain, but soon later it was maintained subculturing through streptomycin containing Ogawa medium slants. Bacillary suspension was prepared by grinding bacillary mass scraped from cultures on Ogawa medium slants in a round flask of $300 \mathrm{cc}$ capacity containing 60 crystal beads of $7 \mathrm{~mm}$ diameter, adding distilled water drop by drop. Suspension density was adjusted comparing with the standard $1 \mathrm{mg}$ per cc suspension.

\section{Process of the Present Study}

At first, an isoniazid resistant variant of a streptomycin dependent strain $18 \mathrm{~b}$ was isolated in a single step and named 18bR-INH. Later use of this particular strain demonstrated that all streptomycin nondependent strains obtained from 18bR-INH remained resistant to isoniazid in a pure bacterial population. This observation was considered as one of the evidences to prove that variation from streptomycin dependence to nondependence is a mutational change. Then, examining many such nondependent strains, it was found that these strains were not the same as their ancester strain H2 in their response to streptomycin. Particularly from some of those nondependent strains, streptomycin enhanced colonies were isolated so frequently on streptomycin containing media that such variation to streptomycin enhanced state was not considered as mutation any more. What was described above was an outline of expermiental process in the present study. Detail will be described as follows. 


\section{EXPERIMENTAL}

Experiment 1: Single Step Isolation of Isoniazid Resistant Variants from 18b Strain.

Ogawa egg slants without or with streptomycin of $100 \mu \mathrm{g}$ per cc were further added with isoniazid in the final concentrations of $0,1,5,10,50$ and $100 \mu \mathrm{g}$ per cc. To streptomycin containing slants, $18 \mathrm{~b}$ strain was inoculated in the amount of $16 \times 10^{6}$ viable units per slant. To streptomycin free slants, H2 strain was inoculated in the amount of $18 \times 10^{6}$ viable units per slant. After 11 weeks incubation at $37^{\circ} \mathrm{C}$, colony counting was made. The result was shown in Table 1. There was no particular difference in colony formation between these two

Table 1. Single step isolation of isoniazid resistant variants on Ogawa medium with a heavy inoculum (1 mg) of tubercle bacilli (Streptomycin sensitive $\mathrm{H} 2$ strain and its streptomycin dependent daughter strain $18 \mathrm{~b}$ )

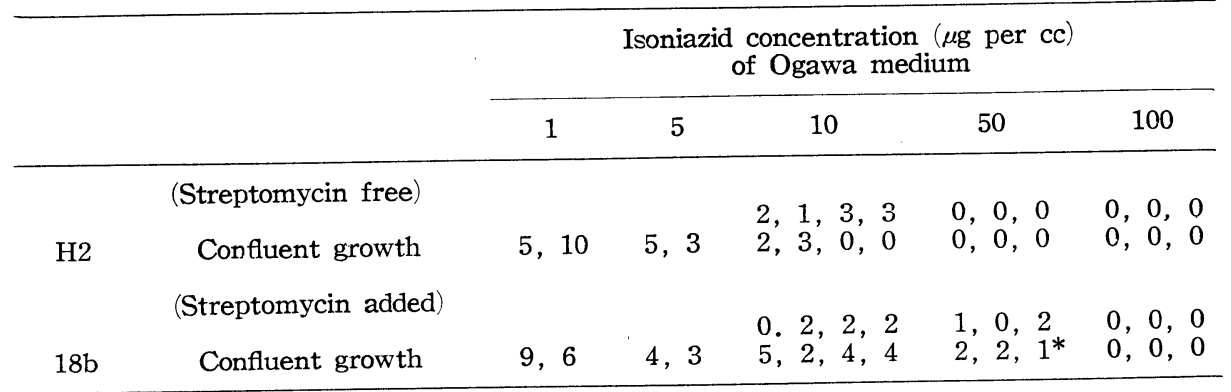

Each figure in the table indicates the number of emergent colonies on each slant. Colony counting was made 11 weeks after sowing $1 \mathrm{mg}$ of the bacilli per slant.

* This colony was thereafter subcultured on Ogawa medium containing both streptomycin and isoniazid in the concentration of 100 and $50 \mu \mathrm{g}$ per cc respectively, six times during six months, and designated as $18 \mathrm{bR}-\mathrm{INH}$ strain.

strains except that a few colonies appeared from $18 \mathrm{~b}$ but not from $\mathrm{H} 2$ on the slants of $50 \mu \mathrm{g}$ isoniazid per cc. These isoniazid resistant variants were obtained in a proportion of about one in $10^{7}$ parent cells. One of these variant colonies on isoniazid $50 \mu \mathrm{g}$ per $\mathrm{cc}$ was then subcultured on slants of the same drug concentrations, namely, $100 \mu \mathrm{g}$ streptomycin and $50 \mu \mathrm{g}$ isoniazid per cc, for six months with one week intervals. Subculture growth was first extremely dysgonic, but with the advance of subculture generation it became more and more eugonic. At this time, this strain was named 18bR-INH.

Experiment 2: Population Purity Test of 18bR-INH Strain with Respect to Isoniazid Resistance and Streptomycin Dependence.

Four kinds of Ogawa slants were prepared containing no drug $100 \mu \mathrm{g}$ streptomycin per cc, $50 \mu \mathrm{g}$ isoniazid per cc, and both streptomycin and isoniazid in the above concentrations. Serial ten-fold dilutions of a bacterial suspension of $18 \mathrm{bR}$ INH were prepared and inoculated onto those slants in the amount of $0.1 \mathrm{cc}$. Colony counting was made after six weeks incubation at $37^{\circ} \mathrm{C}$. The result was shown in Table 2. The table indicates that $18 \mathrm{bR}-\mathrm{INH}$ is a purely populated strain with respect to streptomycin dependence and isoniazid resistance of the present 
Table 2. Purity test of $18 \mathrm{bR}-\mathrm{INH}$ strain concerning its isoniazid resistance and streptomycin dependence

\begin{tabular}{|c|c|c|c|c|}
\hline \multirow{2}{*}{$\begin{array}{l}\text { Size of } \\
\text { inoculum }\end{array}$} & \multirow{2}{*}{ Drug free } & \multicolumn{3}{|c|}{ Drug concentration ( $\mu \mathrm{g}$ per $\mathrm{cc}$ ) } \\
\hline & & Streptomycin 100 & Isoniazid 50 & $\begin{array}{l}\text { Streptomycin } 100 \\
\text { Isoniazid } 50\end{array}$ \\
\hline $\begin{array}{l}\text { *Original } \\
\text { bacillary } \\
\text { suspension }\end{array}$ & $\begin{array}{l}0,0,2,0,2,0 \\
0,1,0,1,1,0 \\
0,0,0,0,0,0\end{array}$ & $\mathrm{HH}, \mathrm{HH}$ & $\begin{array}{l}0,0,0,0,1,0 \\
0,0,0.0,0,1 \\
0,0,0,0,0,0\end{array}$ & $\mathrm{HH}, \mathrm{HH}$ \\
\hline $1: 10$ & $0,0,0,1,0,0$ & $\mathrm{HH}, \mathrm{HH}$ & & $\mathrm{HH}, \mathrm{Ht}$ \\
\hline $1: 10^{2}$ & & $\mathrm{HH}, \mathrm{Ht}$ & & $\mathrm{HH}, \mathrm{HH}$ \\
\hline $1: 10^{3}$ & & $\mathrm{HH}, \mathrm{HH}$ & & $\mathrm{HH}, \mathrm{HH}$ \\
\hline $1: 10^{4}$ & &,++ & &,++ \\
\hline $1: 10^{5}$ & & $32,52,24,32,42$ & & $3639,21,25,35$ \\
\hline $1: 10^{6}$ & & $1,2,4,5,3$ & & $0,6,1,2,3$ \\
\hline $1: 10^{7}$ & & $0,1,0,0$ & & $0,0,1,0$ \\
\hline
\end{tabular}

Ht Surface of medium covered with confluent growth.

+ Over 100 colonies.

Figures in the table indicate the number of emergent colonies on each slant.

Colony counting was made at six weeks.

* After ten weeks, colony formation increased as follows ;

$\{$ Drug free: total 18 colonies in 18 slants.

\{ Isoniazid $50 \mu \mathrm{g}$ per $\mathrm{cc}$ : total 11 colonies in 18 slants.

drug concentrations. One more observation worthy of mentioning is that, with heavy inocula of this strain, late colony growth appeared in media of no drug or of isonizid only possibly due to the presence of streptomycin nondependent mutants in a proportion of about one in $10^{6}$ to $10^{7}$ dependent cells. At this time, we received an impression that such colony formation was more frequent in media of no drug than in those of $50 \mu \mathrm{g}$ isoniazid per cc. More detail analysis was made later on this point.

Experiment 3: Streptomycin Dependency Test of $18 b$ and 18bR-INH.

Ogawa medium slants without or with streptomycin ranging from 640 to $10 \mu \mathrm{g}$ per $\mathrm{cc}$ in two-fold dilution were prepared. Serial ten-fold dilutions of bacterial suspensions of $18 \mathrm{~b}$ and $18 \mathrm{bR}$-INH were inoculated onto these slants in the amount of $0.1 \mathrm{cc}$ per slant. Colony counting was made after 4 weeks incubation at $37^{\circ} \mathrm{C}$. The result was shown in Table 3. Normal eugonic growth was observed on media of over $40 \mu \mathrm{g}$ streptomycin per cc in both strains. The growth on $20 \mu \mathrm{g}$ per cc was extremely dysgonic and no growth appeared on $10 \mu \mathrm{g}$ per $\mathrm{cc}$ and streptomycin free media. From this table, it would be understood that streptomycin nondependent variants shown in Table 2 were quite discontinuously occurring from the parent $18 \mathrm{bR}-\mathrm{INH}$ strain.

Experiment 4: Single Step Isolation of Streptomycin Nondependent Mutants from 18bR-INH in Drug Free Isoniazid Containing Media.

As stated in Experiment 2, we received an impression that streptomycin nondependent variants can be obtained from 18bR-INH more frequently in drug free media than in those containing isoniazid of $50 \mu \mathrm{g}$ per $\mathrm{cc}$, despite that the strain is the pure population of cells resistant to this concentration of the drug. 
Table 3. Streptomycin dependency test of $18 \mathrm{~b}$ and its variant $18 \mathrm{bR}-\mathrm{INH}$ strain

\begin{tabular}{c} 
Dilution \\
\cline { 2 - 9 }
\end{tabular}

Each dilution was inoculated in the amount of $0.1 \mathrm{cc}$ per slant.

$\mathrm{H}$ S Surface of medium covered with confluent growth.

H Innumerable distinct colonies.

+ Over 100 colonies.

* Dysgonic growth.

In order to confirm this observation, six separate experiments were conducted to isolate streptomycin nondependent colonies from heavy inocula of $18 \mathrm{bR}-\mathrm{INH}$ comparing such two different cases as above. The results were summarized in Table 4. In every case, our previous finding was reproduced. Then, nondependent mutants were isolated on media containing isoniazid in $1,5,10$ and $50 \mu \mathrm{g}$ per cc comparing with the case on drug free media. Colony counting was made at 5,7 and 9 weeks after incubation at $37^{\circ} \mathrm{C}$. The results were summarized in Table 5 , which indicates that isoniazid of the lower concentrations than $10 \mu \mathrm{g}$ dose not

Table 4. Single step isolation of streptomycin nondependent mutants from $18 \mathrm{bR}-\mathrm{INH}$ strain in drug free or isoniazid containing environment

\begin{tabular}{lcccccc}
\hline & \multicolumn{7}{c}{ Experiment } \\
\cline { 2 - 7 } & $\mathrm{a}$ & $\mathrm{b}$ & $\mathrm{c}$ & $\mathrm{d}$ & $\mathrm{e}$ & $\mathrm{f}$ \\
\hline $\begin{array}{c}\text { Viable bacterial cells } \\
\text { examined }\end{array}$ & $8 \times 17^{7}$ & $6 \times 10^{7}$ & $12 \times 10^{7}$ & $5.6 \times 10^{7}$ & $7.6 \times 10^{8}$ & $2.3 \times 10^{7}$ \\
$\begin{array}{c}\text { Nondependent mutants } \\
\text { on drug free Ogawa } \\
\text { medium }\end{array}$ & 80 & 18 & 61 & 83 & 221 & 46 \\
$\begin{array}{c}\text { Nondependent mutants } \\
\text { on Ogawa medium of }\end{array}$ & 32 & 5 & 13 & 7 & 9 & 1 \\
$\begin{array}{c}50 \mu \mathrm{g} \text { per cc isoniazid } \\
\text { Counted at w weeks }\end{array}$ & 6 & 4 & 5 & 11 & 8 & 5 \\
\hline
\end{tabular}

At each experiment, the population purity of $18 \mathrm{bR}-\mathrm{INH}$ was confirmed with respect to streptomycin dependence and isoniazid resistance. 
Table 5. Feature of late growth of nondependent mutant colonies from $18 \mathrm{bR}-\mathrm{INH}$ strain on various concentrations of isoniazid

\begin{tabular}{lcrccc} 
& & \multicolumn{4}{c}{ Drug concentration $(\mu \mathrm{g}$ per cc) } \\
\cline { 3 - 6 } Counted at & No drug & \multicolumn{1}{c}{1} & 5 & 10 & 50 \\
\hline 5 weeks & 46 & 54 & 57 & 50 & 1 \\
7 weeks & 122 & 166 & 144 & 121 & 4 \\
9 weeks & 202 & 225 & 234 & 185 & 6 \\
\hline
\end{tabular}

Figures in the table indicate emergent colonies grown out of $2.3 \times 10^{7}$ viable streptomycin dependent cells inoculated.

The result of purity test of $18 \mathrm{bR}-\mathrm{INH}$ strain at the time of inoculation was as follows :

\begin{tabular}{|c|c|}
\hline $\left.\begin{array}{l}\text { Colony formation on } \\
\text { each slant inoculated } \\
\text { with } 10^{-6} \mathrm{mg} \text { of the } \\
\text { strain. }\end{array}\right\}$ & $\left.\begin{array}{l}\text { Streptomycin of } 100 \mu \mathrm{g} \text { per cc } \\
\text { Streptomycin of } 100 \mu \mathrm{g} \text { per cc } \\
\text { Isoniazid of } 50 \mu \mathrm{g} \text { per cc }\end{array}\right\}$ \\
\hline
\end{tabular}

interfere with mutation to streptomycin nondependence, but that of $50 \mu \mathrm{g}$ per cc produces such effects as stated above.

Experiment 5: Single Step Isolation of Streptomycin Nondependent Colonies from 18bR-INH on Ogawa Medium without or with Streptomycin in 5 and $10 \mu \mathrm{g}$ per $c c$.

As stated in Experiment 3, 18bR-INH makes normal abundant growth in the environment containing streptomycin of more than $40 \mu \mathrm{g}$ per $\mathrm{cc}$, and extremely dysgonic growth in $20 \mu \mathrm{g}$ per cc. This time, therefore, comparative observation was made concerning the discontinuous occurrence of streptomycin nondependent variants on media without or with streptomycin of 5 or $10 \mu \mathrm{g}$ per cc. Size of the bacterial population under examination was $7 \times 10^{6}$ viable cells per each drug concentration. The result was shown in Table 6 . The table indicates the fact that with increase of streptomycin concentration the number of discrete colony formation increased, although the differences were not so large. This may have been due to the prolongation of residual growth by the presence of 5 and $10 \mu \mathrm{g}$ streptomycin per cc.

Experiment 6: Relation between Size of Inoculum and Occurrence of Streptomycin Nondependent Colonies.

Two independent trials were made to examine the relation between size of inoculum and the number of nondependent variants in $18 \mathrm{bR}-\mathrm{INH}$. The result was

Table 6. Single step isolation of streptomycin nondependent colonies from $18 \mathrm{bR}-\mathrm{INH}$ on Ogawa medium without or with streptomycin in 5 and $10 \mu \mathrm{g}$ per cc

\begin{tabular}{|c|c|c|c|c|c|}
\hline \multirow{2}{*}{$\begin{array}{l}\text { The number of } \\
\text { viable cells } \\
\text { examined }\end{array}$} & \multirow{2}{*}{ No drug } & \multicolumn{4}{|c|}{ Streptomycin concentration ( $\mu \mathrm{g}$ per cc) } \\
\hline & & 5 & 10 & 20 & 320 \\
\hline $7 \times 10^{6}$ & 8 & 11 & 14 & $\begin{array}{c}\mathrm{Ht} \\
\text { (Dysgonic) }\end{array}$ & $\stackrel{\text { Ht }}{\text { (Eugonic) }}$ \\
\hline
\end{tabular}

Each figure indicates discrete or confluent colony growth in the same way as Table 3 . Colony counting was made in 11 weeks. 
Table 7. Single step isolation of streptomycin nondependent colonies on streptomycin free Ogawa medium from serial tenfold dilutions of a 18bR-INH bacillary suspension

\begin{tabular}{cccc}
\hline & & \multicolumn{2}{c}{ Size of inoculum } \\
& Original suspension & $1: 10$ dilution & $1: 10^{2}$ dilution \\
\cline { 3 - 4 } Exp. 1 & $93^{*}$ & 11 & 1 \\
Exp. 2 & $132^{* *}$ & 12 & \\
\hline
\end{tabular}

*, ** These figures indicates the sum of colonies on ten slants counted at 8 weeks after inoculation with $13 \times 10^{5}$ (Exp. 1) or $55 \times 10^{5}$ (Exp. 2) viable cells per slant.

demonstrated in Table 7, which indicated that the number of emergent nondependent colonies was proportional to size of inoculum.

Experiment 7 : Population Analysis of Streptomycin Nondependent Mutant Colonies Isolated in a Single Step from 18bR-INH Strain.

In the course of the present study, streptomycin nondependent mutant colonies have been isolated from one experiment to another both on drug free Ogawa media and on those isoniazid $50 \mu \mathrm{g}$ per cc. Each of these colonies was subcultured on drug free Ogawa media, from which a bacillary suspension was prepared to test its sensitivity or resistance to streptomycin and isoniazid. Total 46 colonies were examined. Serial ten-fold dilutions of the suspensions were inoculated in the amount of $0.1 \mathrm{cc}$ onto Ogawa slants without or with streptomycin in six different concentrations ranging from 320 to $10 \mu \mathrm{g}$ per $\mathrm{cc}$ in two-fold dilution and with isoniazid of $50 \mu \mathrm{g}$ per cc. In this detailed analysis, the behavior to streptomycin of test colonies were not the same but different a little from one colony to another. However, the majority of them had the same tendency of growth as shown in Table 8 (counting in 3 weeks). Namely, those colonies were streptomycin resistant at least in phenotype, but were not pure in the population picture. In the concentrations upto $20 \mu \mathrm{g}$ per cc, growth was the same grade as in drug free media. With the increase of drug concentration from $20 \mu \mathrm{g}$ per cc, growth was became

Table 8. Population analysis of streptomycin nondependent mutant colony isolated in a single step from $18 \mathrm{bR}-\mathrm{INH}$ strain

(The most representative example)

\begin{tabular}{|c|c|c|c|c|c|c|c|c|}
\hline \multirow{3}{*}{ Size of inoculum } & \multicolumn{8}{|c|}{ Drug concentration ( $\mu \mathrm{g}$ per $\mathrm{cc}$ ) } \\
\hline & \multicolumn{7}{|c|}{ Streptomycin } & \multirow{2}{*}{$\frac{\text { Isoniazid }}{50}$} \\
\hline & 0 & 10 & 20 & 40 & 80 & 160 & 320 & \\
\hline Original suspension & HH & HHt & $\mathrm{HH}$ & $\mathrm{Htt}$ & $\mathrm{HH}$ & $\mathrm{HH}$ & $\mathrm{HH}$ & $\mathrm{HH}$ \\
\hline $1: 10^{2}$ & $\mathrm{HH}$ & HH & $\mathrm{HH}$ & $\mathrm{HH}$ & $\mathrm{Htt}$ & H & + & $\mathrm{HH}$ \\
\hline $1: 10^{4}$ & tt & $H$ & $H$ & $H$ & + & 0 & 0 & $H$ \\
\hline $1: 10^{6}$ & 33 & 24 & 31 & 0 & 0 & 0 & 0 & 35 \\
\hline
\end{tabular}

Symbols in the table are the same as those in Table 3.

Reading was made in 3 weeks. 
Table 9. Population analysis of a streptomycin sensitive strain $\mathrm{H} 2$ (The ancestor strain of $18 \mathrm{bR}-\mathrm{INH}$ strain)

\begin{tabular}{|c|c|c|c|c|c|c|c|c|}
\hline \multirow{3}{*}{ Size of inoculum } & \multicolumn{8}{|c|}{ Drug concentration ( $\mu \mathrm{g}$ per cc) } \\
\hline & \multicolumn{7}{|c|}{ Streptomycin } & \multirow{2}{*}{$\frac{\text { Isoniazid }}{50}$} \\
\hline & 0 & 10 & 20 & 40 & 80 & 160 & 320 & \\
\hline Original suspension & $\mathrm{HH}$ & 83 & 36 & 1 & 2 & 1 & 1 & 2 \\
\hline $1: 10$ & $H$ & 19 & 5 & 0 & 0 & 0 & 0 & 0 \\
\hline $1: 10^{2}$ & $\mathrm{HH}$ & 1 & 0 & 0 & 0 & 0 & 0 & 0 \\
\hline $1: 10^{4}$ & $H$ & 0 & 0 & 0 & 0 & 0 & 0 & 0 \\
\hline $1: 10^{7}$ & 13 & 0 & 0 & 0 & 0 & 0 & 0 & 0 \\
\hline
\end{tabular}

Sympols in the table are the same as those in Table 3.

Colony counting was made in 10 weeks.

poorer and dysgonic. However, it must be added here that even in a rather high concentration late growth of colonies was acknowledged when counting was made in 5 weeks or later. Besides this type of nondependent colonies, those having the nature of pure resistance or streptomycin enhancement were also obtained. On the other hand, every test colony was found to be resistant to $50 \mu \mathrm{g}$ isoniazid per cc in a pure population. These results should be compared with the case of $\mathrm{H} 2$, an ancester strain of $18 \mathrm{bR}-\mathrm{INH}$, as shown in Table 9. Here, it would be quite evident that streptomycin nondependent variants are not the same as $\mathrm{H} 2$ strain in their sensitivity to streptomycin. Table 3 is to classify the 49 nondependent colonies under examination according to their type with respect to the above aspects.

Experiment 8: Recovery of Streptomycin Enhanced Colonies on Media of $500 \mu \mathrm{g}$ per cc from 18bR-INH.

Despite of much possibility that variation from streptomycin dependence to nondependence is a single gene mutation, most of the nondependent colonies examined in the previous experiment were unexpectedly a nonpure bacterial popula-

Table 10. Type classification of 49 streptomycin nondependent mutant colonies isolated in a single step from $18 \mathrm{bR}-\mathrm{INH}$ strain

\begin{tabular}{|c|c|c|c|c|c|c|}
\hline \multirow{2}{*}{$\begin{array}{l}\text { No. of colonies } \\
\text { examined }\end{array}$} & \multicolumn{4}{|c|}{ To streptomycin } & \multicolumn{2}{|c|}{ To isoniazid } \\
\hline & $\begin{array}{c}\text { Sensitive } \\
\text { (Table } 9 \text { type) }\end{array}$ & $\begin{array}{c}\text { Table } 8 \\
\text { type }\end{array}$ & $\begin{array}{l}\text { Resistant } \\
\text { completely }\end{array}$ & Enhanced & Sensitive & $\begin{array}{l}\text { Resistant } \\
\text { completely }\end{array}$ \\
\hline $39 * *$ & 0 & 32 & 3 & 4 & 0 & 39 \\
\hline $10^{*}$ & 0 & 10 & 0 & 0 & 0 & 10 \\
\hline Total & 0 & 42 & 3 & 4 & 0 & 49 \\
\hline
\end{tabular}

* Streptomycin nondependent colonies isolated on isoniazid containing medium.

** Streptomycin nondependent colonies isolated on isoniazid free medium.

Complete resistance to isoniazid indicates the case of pure bacterial population to $50 \mu \mathrm{g}$ per cc.

Complete resistance to streptomycin indicates the case of pure bacterial population to 320 $\mu \mathrm{g}$ per $\mathrm{cc}$. 
Table 11. Type classification of the colonies appeared on streptomycin containing Ogawa medium ( $500 \mu \mathrm{g}$ per $\mathrm{cc}$ ) inoculated with streptomycin nondependent strains obtained from $18 \mathrm{bR}-\mathrm{INH}$ strain

\begin{tabular}{|c|c|c|c|c|c|}
\hline \multirow{2}{*}{$\begin{array}{l}\text { Nondependent colonies } \\
\text { from which tested } \\
\text { colonies were obtained }\end{array}$} & \multirow{2}{*}{$\begin{array}{l}\text { No. of } \\
\text { colonies } \\
\text { tested }\end{array}$} & \multicolumn{4}{|c|}{$\begin{array}{l}\text { Type classification } \\
\text { (with respect to streptomycin) }\end{array}$} \\
\hline & & $\begin{array}{c}\text { Table } 8 \\
\text { type }\end{array}$ & Resistant & Enhanced* & $\begin{array}{c}\text { Dependent } \\
\text { (Table } 3 \text { type) }\end{array}$ \\
\hline$a$ & 3 & 1 & 2 & 0 & 0 \\
\hline $\mathrm{b}$ & 5 & 1 & 3 & 1 & 0 \\
\hline$c$ & 8 & 2 & 4 & 2 & 0 \\
\hline $\mathrm{d}$ & 3 & 0 & 0 & 3 & 0 \\
\hline $\mathrm{e}$ & 5 & 0 & 1 & 4 & 0 \\
\hline $\mathrm{f}$ & 5 & 1 & 4 & 0 & 0 \\
\hline
\end{tabular}

Typing was made by serial dilution and inoculation test as shown in Table 8 .

* More rapid and abundant growth in the presence of streptomycin than its absence as shown in Table 12 .

tion of streptomycin resistance, at least in such type of test. As a method to analyse this point, experiments were undertaken as follows.

Inoculating heavy inocula to Ogawa egg slants of $500 \mu \mathrm{g}$ per cc, some discrete colonies were obtained in a single step from six nondependent strains temporarily named $a, b, c, d, e$ and $f$. Then, those colonies were once subcultured on Ogawa media of the same drug concentration. Using these cultures, tests were made in the same manner as described in Experiment 7 . Summarizing the results, the behavior of these cultures to streptomycin was classified into three types as shown in Table 11, namely, Table 8 type, streptomycin resistant and streptomycin enhanced. Interesting was the observation that streptomycin enhanced colonies were obtained in a high proportion among those tested, especially from a certain nondependent strain such as $\mathrm{d}$ and e. The growth characteristics of streptomycin enhanced cultures were demonstrated in Table 12. Growth differences between

Table 12. Growth characteristics of a streptomycin enhanced strain isolated from a streptomycin nondependent strain (b strain in Table 11)

\begin{tabular}{|c|c|c|c|c|c|c|c|c|}
\hline \multirow{2}{*}{\multicolumn{2}{|c|}{ Size of inoculum }} & \multicolumn{7}{|c|}{ Streptomycin concentration ( $\mu \mathrm{g}$ per cc) } \\
\hline & & 1 & 10 & 20 & 40 & 80 & 160 & 320 \\
\hline \multirow{3}{*}{ Read at 3 weeks } & $\int 10^{-1}$ & $+^{*}$ & $H$ & $\mathrm{HH}$ & $\mathrm{HH}$ & $H$ & $\mathrm{HH}$ & $\mathrm{HH}$ \\
\hline & $10^{-3}$ & $+*$ & $+^{*}$ & $H$ & $H$ & $H$ & $H$ & $H$ \\
\hline & $10^{-5}$ & 0 & $15^{*}$ & 17 & 21 & 29 & 22 & 30 \\
\hline \multirow{3}{*}{ Read at 5 weeks } & $\left\{10^{-5}\right.$ & $H *$ & HH & HH & HH & HH & H & Ht \\
\hline & $10^{-3}$ & $+*$ & $H$ & Htt & $H$ & $\mathrm{Htt}$ & $\mathrm{Ht}$ & Htt \\
\hline & $10^{-5}$ & $10^{*}$ & 18 & 19 & 22 & 31 & 23 & 33 \\
\hline
\end{tabular}

* Dysgonic growth

Symbols are the same as those in Table 3. 
Table 13. Type classification of the colonies appeared on Ogawa medium containing various concentrations of streptomycin inoculated with a streptomycin nondependent strain e

\begin{tabular}{|c|c|c|c|c|c|}
\hline \multirow{2}{*}{$\begin{array}{l}\text { Streptomycin } \\
\text { concentration of the } \\
\text { medium on which } \\
\text { tested colonies } \\
\text { were isolated }\end{array}$} & \multirow{2}{*}{$\begin{array}{l}\text { No. of } \\
\text { colonies } \\
\text { tested }\end{array}$} & \multicolumn{4}{|c|}{$\begin{array}{l}\text { Type classification } \\
\text { (with respect to streptomycin) }\end{array}$} \\
\hline & & Table 8 type & Resistant & Enhanced & Dependent \\
\hline \multicolumn{6}{|l|}{$(\mu \mathrm{g}$ per $\mathrm{cc})$} \\
\hline 1000 & 10 & 0 & 5 & 5 & 0 \\
\hline 500 & 8 & 0 & 5 & 3 & 0 \\
\hline 100 & 16 & 14 & 2 & 2 & 0 \\
\hline 50 & 8 & 8 & 0 & 0 & 0 \\
\hline
\end{tabular}

18bR-INH and such enhanced strains were that the latter could make normal growth in $10 \mu \mathrm{g}$ per $\mathrm{cc}$ and also a delayed and dysgonic growth even drug free media. In order to analyse the above observations in more detail, a similar experiment was made using a streptomycin nondependent strain e only. This time, however, e strain was inoculated onto Ogawa egg slants of various concentrations of streptomycin such as $1000,500,100,50 \mu \mathrm{g}$ per cc. Then emergent colonies on each drug concentration were examined as before. The results were summarized in Table 13. The table indicates that the appearance of streptomycin enhanced colonies was in a more frequent rate in higher concentrations of streptomycin.

Experiment 9: Growth Characteristics of a Streptomycin Nondependent Strain $e$, Particularly the Frequent Emergence of Streptomycin Enhanced Colonies from It.

A more detailed analysis of the growth of a streptomycin nondependent strain e was attempted just like Experiment 7 (Table 8). As shown in Table 14, colonies appeared even in the streptomycin environment of 80 to $640 \mu \mathrm{g}$ per cc in the number of about one tenth to one twentyth of that in drug free media. When retested, all these colonies were found to be streptomycin enhanced. This observation appears a very remarkable one if we recall the fact reported by Hashimoto (1955) that streptomycin enhanced colonies were obtained by him from H2 strain, the ancester strain of e strain, as an extremely rare variant (about one to $10^{8} \sim$ $10^{9}$ normal cells). This observation appears particularly important to understand the biological significance of the bacterial variation from streptomycin dependence to nondependence.

Experiment 10: Growth Characteristics of a Streptomycin Nondependent Strain c, Particularly as an Example of the True Reversion to Streptomycin Dependence.

The same kind of experiment as the preceding one was conducted using another streptomycin nondependent strain c. In this case, emergence of enhanced colonies was less frequent than the previous case. However, one of the colonies obtained at $640 \mu \mathrm{g}$ per $\mathrm{cc}$ was streptomycin dependent possessing the same growth characteristics as 18bR-INH. In Table 16, it was shown. A streptomycin dependent strain 18b was isolated by Hashimoto (1955) from H2 strain as an extremely rare mutant (about one to $10^{9} \sim 10^{10}$ normal cells), but in the present experiment the dependent colony can be presumed to have occurred as a more common variant. 
Table 14. Growth of a streptomycin nondependent strain e and the emergence of streptomycin enhanced colonies from it in the environment

of high streptomycin concentrations

\begin{tabular}{ccccccccc}
\hline \multirow{2}{*}{$\begin{array}{c}\text { Size of } \\
\text { inoculum mg }\end{array}$} & 0 & 10 & 20 & 40 & 80 & 160 & 320 & 640 \\
\cline { 2 - 8 } & $\mathrm{HH}$ & $\mathrm{HH}$ & $\mathrm{HH}$ & $\mathrm{HH}$ & $\mathrm{HH}$ & $\mathrm{HH}$ & $\mathrm{HH}$ & $\mathrm{H}$ \\
$10^{-1}$ & $\mathrm{HH}$ & $\mathrm{HHt}$ & $\mathrm{HH}$ & $\mathrm{HH}$ & $\mathrm{HH}$ & $\mathrm{HH}$ & $\mathrm{HH}$ & + \\
$10^{-3}$ & 21 & 23 & 3 & $\mathrm{H}$ & $\mathrm{C}$ & (2) & (1) \\
$10^{-6}$ & 24 & 21 &
\end{tabular}

Type classification was made of five colonies out of those circled above.

The results were as below.

\begin{tabular}{ccl}
\hline $\begin{array}{c}\text { Streptomycin concentration of } \\
\text { the medium on which tested } \\
\text { colonies were isolated }\end{array}$ & $\begin{array}{c}\text { No. of colonies } \\
\text { tested }\end{array}$ & $\begin{array}{c}\text { Type } \\
\text { (behaviour to streptomycin) }\end{array}$ \\
\hline$(\mu \mathrm{g}$ per cc) & & \\
80 & 1 & Enhanced \\
160 & 1 & Enhanced \\
320 & 2 & Enhanced, Enhanced \\
640 & 1 & Enhanced \\
\hline
\end{tabular}

Table 15. Growth of a streptomycin nondependent strain $c$ and the emergence of streptomycin enhanced and dependent colonies from it in the environment of high streptomycin concentrations

\begin{tabular}{ccccccccc}
\hline \multirow{2}{*}{$\begin{array}{c}\text { Size of } \\
\text { inoculum mg }\end{array}$} & 0 & 10 & 20 & 40 & 80 & 160 & 320 & 640 \\
\hline & 0 & Streptomycin concentration $(\mu \mathrm{g}$ per cc) \\
$10^{-1}$ & $\mathrm{HH}$ & $\mathrm{HH}$ & $\mathrm{HH}$ & $\mathrm{HH}$ & $\mathrm{HH}$ & $\mathrm{H}$ & $\mathrm{H}$ & $\oplus$ \\
$10^{-3}$ & $\mathrm{HH}$ & $\mathrm{HH}$ & $\mathrm{HH}$ & $\mathrm{HH}$ & $\mathrm{H}+$ & + & + & 0 \\
$10^{-5}$ & + & + & + & + & 4t & 0 & 0 & 0 \\
$10^{-5}$ & 27 & 20 & (15) & (16) & 0 & 0 & 0 & 0 \\
\hline
\end{tabular}

Type classification was made of 21 colonies out of those circled above.

The results were as below.

\begin{tabular}{ccccc}
\hline \multirow{2}{*}{$\begin{array}{c}\text { Streptomycin concentration } \\
\text { of the medium on which } \\
\text { tested colonies were isolated }\end{array}$} & No. of colonies & \multicolumn{3}{c}{ Type (bevaviour to streptomycin) } \\
\cline { 3 - 5 } & tested & Parent type* & Enhanced & Dependent \\
\hline ( $\mathrm{g}$ per cc) & 4 & 4 & 0 & 0 \\
20 & 5 & 5 & 0 & 0 \\
40 & 4 & 4 & 0 & 0 \\
80 & 8 & 6 & 1 & 1 \\
640 & 5 & & & \\
\hline
\end{tabular}

Note: * Growth type as demonstrated in the above half of this table. 
Table 16. Streptomycin dependency and purity test of a streptomycin dependent strain reisolated from a streptomycin nondependent strain $c$ in Table 15

\begin{tabular}{|c|c|c|c|c|c|c|}
\hline \multirow{3}{*}{$\begin{array}{l}\text { Size of } \\
\text { inoculum } \\
\text { mg }\end{array}$} & \multirow{3}{*}{ No drug } & \multicolumn{5}{|c|}{ Drug concentration ( $\mu \mathrm{g}$ per $\mathrm{cc}$ ) } \\
\hline & & \multicolumn{3}{|c|}{ Streptomycin } & \multirow{2}{*}{$\begin{array}{c}\text { Isoniazid } \\
50\end{array}$} & \multirow{2}{*}{$\begin{array}{lr}\text { Streptomycin } & 100 \\
\text { Isoniazid } & 50\end{array}$} \\
\hline & & 20 & 100 & 500 & & \\
\hline 1 & $\begin{array}{r}* 1,0,3,4 \\
4,1,0,0,0\end{array}$ & \multicolumn{5}{|c|}{$* * 0,0,0,0,0$} \\
\hline $10^{-1}$ & 0,0 &,++ & $\mathrm{HH}, \mathrm{HH}$ & $\mathrm{HH}, \mathrm{HH}$ & 0,0 & $\mathrm{HH}, \mathrm{HH}$ \\
\hline $10^{-2}$ & 0,0 &,++ & $H+H$ & $H+H$ & 0,0 & $\mathrm{HH}, \mathrm{HH}$ \\
\hline $10^{-3}$ & 0,0 & 0,0 & $H, H$ & $H, H$ & 0,0 & $H, H$ \\
\hline $10^{-4}$ & 0,0 & 0,0 &,++ &,++ & 0,0 &,++ \\
\hline $10^{-5}$ & 0,0 & 0,0 & 23,38 & 43,48 & 0,0 & 23,33 \\
\hline
\end{tabular}

This streptomycin dependent strain was named $18 \mathrm{bR}-\mathrm{INH}^{\prime}$.

Colony counting was made at 4 weeks.

$*(3,3,5,6,5,3,3,4,2)$

$* *(0,1,0,2,1 * * *)$

at 8 weeks.

*** This streptomycin nondependent strain was named $\mathrm{c}^{\prime}$.

Table 17. Type classification of the colonies appeared on Ogawa medium containing various concentrations of streptomycin inoculated with a streptomycin nondependent strain $c^{\prime}$

\begin{tabular}{|c|c|c|c|c|c|}
\hline \multirow{2}{*}{$\begin{array}{l}\text { Streptomycin } \\
\text { concentration of the } \\
\text { medium on which } \\
\text { tested colonies } \\
\text { were isolated }\end{array}$} & \multirow{2}{*}{$\begin{array}{l}\text { No. of } \\
\text { colonies } \\
\text { tested }\end{array}$} & \multicolumn{4}{|c|}{$\begin{array}{l}\text { Type classification } \\
\text { (with respect to streptomycin) }\end{array}$} \\
\hline & & $\begin{array}{l}\text { Table } 8 \\
\text { type }\end{array}$ & Resistant & Enhanced & Dependent \\
\hline \multicolumn{6}{|l|}{ ( $\mu \mathrm{g}$ per cc) } \\
\hline 500 & 10 & 0 & 3 & 7 & 0 \\
\hline 100 & 14 & 0 & 1 & 13 & 0 \\
\hline 50 & 6 & 0 & 2 & 4 & 0 \\
\hline
\end{tabular}

Table 18. Stability of the enhanced state of a streptomycin enhanced strain obtained from a streptomycin nondependent strain $c^{\prime}$

\begin{tabular}{|c|c|c|c|c|c|}
\hline & & \multirow{2}{*}{ No drug } & \multicolumn{3}{|c|}{ Streptomycin concentration ( $\mu \mathrm{g}$ per $\mathrm{cc}$ ) } \\
\hline & & & 10 & 100 & 300 \\
\hline Nov. 4,57 & & $+*$ & + & 曲 & HH \\
\hline Jan. 30,58 & & $\oplus *_{\mathrm{a}}$ & + & $\bigoplus_{\mathrm{b}}$ & tH \\
\hline \multirow{2}{*}{ Apr. 12,58} & a & $t^{*}$ & H & $\mathrm{HH}$ & HH \\
\hline & $\mathrm{b}$ & - & $H$ & 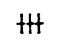 & $\mathrm{HH}$ \\
\hline
\end{tabular}

Symbols are the same as those in Table 3.

* Dysgonic growth.

Circled culture was tested in the next generation. 
However, it must be noted that the streptomycin dependent strain regained here (18bR-INH') produced streptomycin nondependent variants in almost the same frequency as the 18bR-INH strain as shown in Table 16 . One of these nondependent mutants was named c' and preserved being presumed that this might be a particular strain of frequent mutability reversible between streptomycin nondependence and dependence. Then, the same kind of analysis as Table 13 was made concerning this strain to examine the feature of occurrence of streptomycin enhanced colonies. The results were summarized in Table 17. Comparison between Table 13 and Table 17 will indicate that c' strain has more chances to produce enhanced colonies instead of resistant ones than e strain. One of the streptomycin enhanced strain obtained from c' was then examined of its stability. As shown in Table 18, it was found stable with respect to that property even after passage through drug free media.

\section{Discussion}

Variation from streptomycin dependence to nondependence occurred showing some characteristics as a mutational change in the strain 18bR-INH, namely it occurred discontinuously in a single step, extremely rarely but in a certain rate in a definite environment, spontaneously, and independently to another nature of isoniazid resistance. In this case, it is easily supposed that this bacterial variation is due to single gene mutation.

However, nondependent strains obtained from 18bR-INH were not the same in their population picture with respect to streptomycin resistance as their ancester strain H2. Therefore, there arose a doubt whether or not nondependent strains are truly back (reverse) mutants. Furthermore, the authors encountered with an interesting observation that streptomycin enhanced colonies emerged from some of those nondependent strains at an extremely higher rate than from the ancester strain $\mathrm{H} 2$.

Under these circumstances, it appears more probable that nondependent strains, at least some of them, are not true back mutants due to a single gene mutation, but they resulted from an independent mutation or from suppressor genes which reverse the effects of mutations at other loci. One good example of such case was recently reported by Yanofsky (1956) in tryptophan requring mutants of Neurospora, which restore the ability to grow in the absence of added tryptophan by a suppressor gene. If the same is true with the case of streptomycin nondependent strains under investigation, they must retain the genetic determinants controlling streptomycin dependence as a masked gene or something recessive to the suppressor gene at least in the streptomycin free environment. In association with this way of thinking, a report of Hashimoto (1955) is especially interesting. He proved by his transformation experiment using Pneumococcus that streptomycin nondependent strains contain DNA which is active in transforming streptomycin sensitive cells to streptomycin dependent ones. The above considerations lead us to an assumption that streptomycin nondependent strains have both streptomycin dependence controlling loci and corresponding suppressor genes, and that in the presence of streptomycin the dependence controlling genes are again activated to adapt for such drug environment. In this way of explanation, emergence of streptomycin enhanced 
colonies from some of streptomycin nondependent strains will be reasonably understood. In other words, nondependent strains can live in streptomycin free media under the dominance of suppressor genes and can survive also in the presence of streptomycin under the dominance of streptomycin dependence controlling genes in turn. In fact, according to Hotchkiss (1956), dominance relationships may be modified by other genes and by environmental factors. This biological adaptation may be called the phenotypic variation (Ephrussi, 1956), namely a manifestation of latent abilities (potentialities) induced by streptomycin without accompanying any genetic change (genotypic variation). Similar situation has ever been postulated by Bryson and Szybalski (1955) to account for some cases of bacterial drug resistance. They employed the term "inducibility", which means the genetic potentiality of microorganisms capable of phenotypic changes in response to substrate alterations or drug addition. They added that even when all cells are genetically inducible, actual induction occurs only in occasional individuals, following a normal or Poissonian distribution, and that the change is confined to a few physiologically competent cells and the majority are sterilized before induction can take place. These things cited above appear important to understand our present experiments. A kind of feedback system may be postulated in such streptomycin nondependent strains. To confirm the hypothesis as above experimentally, further attempts are now under way and moving along in a satisfactory fashion. They will be reported in a subsequent paper.

\section{SuMMARY}

Variation from streptomycin dependence to nondependence in a streptomycin dependent strain of tubercle bacilli $18 \mathrm{bR}-\mathrm{INH}$ had some characteristics as a mutational change. Detailed population analysis indicated, however, that this variation is sometimes not the real "back (reverse)" mutation. When placed in streptomycin environment, some nondependent strains produced streptomycin enhanced colonies in an unexpectedly high proportion. It was presumed that such streptomycin nondependent strains retained their genes controlling streptomycin dependence as recessive or suppressed determinant even after the change to nondependence, and that in a certain level of streptomycin concentration the gene was again activated to manifest the dependence on streptomycin as a phenotypic variation (adaptation).

Before finishing this paper, we would like to acknowledge the kind advice of Dr. Szybalski in Institute of Microbiology, Rutgers, the State University of New Jersey, who informed me his recent unpublished data that recombination experiments with strain K-12 of $E$. coli pres. ented a good evidence to prove that reversion to streptomycin nondependence is a suppressor mutation.

\section{REFERENCES}

BERTANI, G. (1951): A method for detection of mutations, using streptomycin dependence in Escherichia coli. Genetics, 36, 598-611.

BRYSON, V. \& SzYBALSKI, W. (1955): Microbial drug resistance. Advances in Gnetics, 7 , $1-46$.

Demerec, M., Wallace, B., Witkin, E. M. \& Bertani, G. (1949): The gene. Carnegie Inst. Wash. Yr. BK., 48, 154-165. 
EPHRUSSI, B. (1956): Enzymes in cellular differentiation. Enzymes: Units of Biological Structure and Function. Edited by Oliver H. Gaebler, Academic Press INC., Publishers, New York, 29-40.

HERZBERG, M. \& ELBERG, S. (1953): Immunization against brucella infection. I. Isolation and characterization of a streptomycin-depentdent mutant. J. Bact., 66, 585-599.

HeRZBERG, M. \& ELBERG, S. (1953): Immunization against brucella infection. II. Effectiveness of a streptomycin-dependent strain of Brucella melitensis. J. Bact., 66, 600-605.

HASHIMOTO, K. (1955): [Studies on the transformation of streptomycin resistance in Pneumococci. II. Transformation of streptomycin dependence]. “Jap. J. Bact.”, 10, 1049-1053 (text in Japanese).

HASHIMOTO, T. (1955) : [Experimental studies on the mechanism of infection and immunity in tuberculosis from the analytical standpoint of streptomycin-dependent tubercle bacilli. Report I. Isolation and biological characteristics of a streptomycin-dependent mutant, and effect of streptomycin administration on its pathogenicity in guinea pigs]. "Kekkaku ", $30,4-8$ (text in Japanese).

HASHIMOTO, T. (1955): [Experimental studies on the mechanism of infection and immunity in tuberculosis from the standpoint of analysis of streptomycin-dependent tubercle bacilli. 2. Studies on the virulence of back mutants from streptomycin-dependent tubercle bacilli]. "Kekkaku”, 30, 237-241 (text in Japanese).

HotchKISS, R. D. (1956): The genetic organization of the deoxyribonucleate units functioning in bacterial transformations. Enzymes: Units of Biological Structure and Function. Edited by Oliver H. Gaebler, Academic Press INC., Publishers, New York pp. 119-130.

KOSEKI, Y. (1957): Study on streptomycin-dependent tubercle bacilli. Jap. J. Tuberc., 5, $107-121$.

LENERT, T. F. and HobBY, G. L. (1949): Streptomycin-dependent strain of $M$. tuberculosis. Am. Rev. Tuberc., 59, 219-220.

Miller, C. P. \& BONHOFF, M. (1947): Two streptomycin-resistant variants of Meningococcus. J. Bact., 54, 467-482.

MuratA, T. (1953): [Studies on the virulence of streptomycin-resistant tubercle bacilli]. "Kekkaku”, 28, 453-458 (text in Japanese).

PAINE, T. F. Jr. \& FINLAND, M. (1948): Observations on bacteria sensitive to, resistant to, and dependent upon streptomycin. J. Bact., 56, 207-218.

USHIBA, D., TAKAMURA, C. \& JO, I. (1951) : [Streptomycin-resistant and streptomycindependent variants of Salmonella enteritidis. I. Some characteristics of a dependent strain]. "Medicine and Biology", 20, 265-268 (text in Japanese).

VANDERLINDE, R. J. \& YEGIAN, D. (1951): The pathogenicity of streptomycin-dependent tubercle bacilli. J. Bact., 63, 96-99.

Wollman, E. (1946): Quated by LWoff, A. (1946): Some problems connected with spontaneous biochemical mutations in becteria. Cold Spring Harbor Symp., Quant. Biol. 11, 139-155.

YANOFSKY, C. (1956): Gene interactions in enzyme synthesis. Enzymes: Units of Biological Structure and Function. Edited by Oliver H. Gaebler, Academic Press INC., Publishers, New York, 147-160.

YEGIAN, D. \& BUDD, V. (1948): A variant of Mycobacterium ranae repuiring streptomycin for growth. J. Bact., 55, 459-461.

YEGIAN, D. \& VANDERLINDE, R. J. (1949): The biological characteristics of streptomycin dependent Mycobacterium ranae. J. Bact., 57, 169-178.

YEGIAN, D., BuDD, V. \& VANDERLINDE, R. J. (1949) : Streptomycin-dependent tubercle bacilli : A simple method for isolation. J. Bact., 58, 257-259' 